\title{
Field Application of Trichoderma spp. for Controlling the Root- Knot Nematode, Meloidogyne javanica in Peanut Plants
}

\author{
Usama S. Elkelany; Mostafa M.A. Hammam; Wafaa M. A. El-Nagdi \\ and Hassan Abd-El-Khair
}

Plant Pathology Dept., National Research Centre, Dokki, Giza, 12622, Egypt.

Corresponding author email: mmahammam@yahoo.com

\begin{abstract}
A field experiment was conducted to study the effect of three Trichoderma species, $T$. harzianum, T. viride and T. virens on root- knot nematode, Meloidogyne javanica infecting peanut plants, compared to commercial product Bio-Nematon ${ }^{\circledR}$ (Purpureocillium lilacinum) and chemical nematicide of Oxamyl ${ }^{\circledR}$. The averages of total microbial soil community, i.e. aerobic bacteria, spore-forming bacteria and fungi in peanut rhizosphere as well as the frequency $\%$ of common fungi with different treatments, during growing season, were recorded. Treatments significantly $(\mathrm{P}=0.05)$ suppressed $\mathbf{J}_{2}$ in soil and $\mathrm{J}_{2}$, females, galls and egg masses in roots and improved peanut plant growth and yield parameters. At mid-season, Trichoderma spp. had more effective nematicidal effects in reducing nematode parameters than Bio-Nematon ${ }^{\circledR}$ in some cases. The highest percentages reduction in $\mathrm{J}_{2}$ in soil (being 81\%) was recorded with $T$. viride followed $T$. harzianum (77\%) and $T$. virens (73\%), compared to untreated control. At harvest time, $T$. viride recorded the highest nematode reduction in $\mathbf{J}_{2}$ in soil (68\%), but $T$. harzianum recorded the highest reduction in total developmental stages of nematode (68\%), galls (84\%) and egg masses (84\%), compared to $T$. viride, $T$. virens and Bio-Nematon ${ }^{\circledR}$. The treated soil rhizosphere differed in total microbial counts as well as frequency of common fungi according to the tested treatment that increased total microbial counts. The treatments highly increased the growth and yield criteria of peanut as indicated by fresh \& dry weights of plants as well as number \& weight of pods and weight of 100 seeds of peanut plants.
\end{abstract}

Keywords: Biological control, Field application, Trichoderma spp., Meloidogyne javanica, Peanut

\section{INTRODUCTION}

Peanut (Arachis hypogaea L.) is very substantial annual herb legumes in tropical and subtropical areas of the world. The peanut is very important food and oil seed crop and well known as a monetary source in the semi-arid tropics. It is rich in energy and contains health benefit nutrients, minerals, antioxidants and vitamins which are considered an essential for optimum health (Settaluri et al., 2012). In Egypt, peanut is grown in light soils as well as in recently reclaimed sandy areas, where the cultivated area reached to being 190.000 hectare for the season 2017 (Anonymous, 2017). The production of peanut is negatively affected by soil borne fungi as well as plant- 
parasitic nematodes (PPNs), where root-knot nematodes, Meloidogyne spp., are among the major nematodes species that attack peanut plants (Abd-Elgawad, 2014). The most destructive soil-borne fungi, Rhizoctonia solani and Fusarium oxysporum, which attack peanut causing quantitative and qualitative losses of peanut yield (Ziedan, 2000 and Abd-El-Khair et al., 2016).

The PPNs cause great damage to agricultural production on various crops all over the world. Because of the toxic effect of chemical nematicides, it is necessary to develop non-chemicals and eco-friendly control strategies for controlling nematodes. Therefore, Trichoderma spp. may play important roles in biological control of soil borne pathogens or PPNs (Papavizas, 1985 and Bastakoti et al., 2017). T.harzianum and $T$. lignorum could decrease the root-galling index and the number of eggs on roots and improve the growth parameters of nematode-infected plants in short-term experiments. In a long-term experiment, the treatments could improve the growth and yield in nematode-infected plants (Spiegel and Chet, 1998). T. harzianum also could control the root galling of root-knot nematode (Meloidogyne javanica) and increased the fresh weight in nematode-infected tomatoes in greenhouse conditions (Sharon et al., 2001). Shawky et al. (2010) mentioned that T. harzianum highly increased the juvenile mortality of $M$. javanica, at all the exposure periods, especially after $72 \mathrm{hrs}$ in vitro tests. Under greenhouse conditions, T. harzianum increased the total fresh weights of shoots and roots, numbers of branches \& pods, plant height and pods weight/plant of peanut. T. harzianum and $T$. viride, singly or mixture, increased the percentages of juvenile mortality and inhibited the egg hatching of $M$. javanica in vitro tests and field applications (Metwaly et al., 2015). Also, they could suppress the reproduction of nematodes and reduce the root galling as well as increase the tomato plants growth in greenhouse experiment. The antagonistic effect of both fungi was increased with increasing densities of their inocula. Results revealed that $T$. harzianum was better efficacy, than T. viride (Al- Javeed, 2016).

Therefore, this present study was conducted to study the effect of Trichoderma spp., i.e. T. harzianum, T. viride and T.virens in comparison to the commercial product, Bio-Nematon ${ }^{\circledR}$ (Purpureocillium lilacinum formally known as Paecilomyces lilacinus) and chemical nematicide of Oxamyl ${ }^{\circledR}$ against root- knot nematode, $M$. javanica and their effect on soil bacterial and fungal communities in peanut plants, grown in field naturally infested with nematode.

\section{MATERIALS AND METHODS}

\section{Initial soil sample collection}

Soil samples were randomly collected, from each experimental plot, naturally infested with root-knot nematode (Meloidogyne javanica) to determine its initial second juvenile stages $\left(\mathrm{J}_{2} \mathrm{~s}\right)$ according to the method described by Barker (1985). Therefore, five sub-samples (each of it $250 \mathrm{~g}$ ) were collected from each plot at a depth of 15-30 cm one week prior to planting time. Then, soil sub-samples of each plot were mixed well together and then an aliquot of composite soil sample (about 250g) was used for nematode extraction.

\section{Source of peanut seeds}

Seeds of peanut cv. Giza 6, which is susceptible to $M$. javanica, were obtained from Department of Horticulture, Agriculture Research Centre, Ministry of Agriculture, Giza, Egypt. 


\section{Trichoderma spp. isolation and preparation}

Three of Trichoderma species i.e. T. harzianum, T. viride and T.virens were isolated and identified in Plant Pathology Department, National Research Centre, Egypt. Sorghum: Sand: Water (2:2:1, V: V: V) medium in plastic bags were prepared. Then, medium bags were sterilized at $121^{\circ} \mathrm{C}$ for $30 \mathrm{~min}$. Each medium bag was separately inoculated with each Trichoderma spp. and then incubated at $30{ }^{\circ} \mathrm{C} \pm 2$ for 14 days. Each inoculum of Trichoderma spp. was adjusted to $1 \times 10^{8}$ propagules and applied at $200 \mathrm{~g}$ per $\mathrm{m}^{2}$. The commercial product of Bio-Nematon ${ }^{\circledR}$ (P.lilacinum, $10^{8}$ unit $/ \mathrm{ml}$ ) and chemical nematicide of Oxamyl ${ }^{\circledR}$ at 3 litre per Feddan were applied for comparison.

\section{Field experiment}

The experiment were conducted, during growing season of 2019, in a clay loam soilnaturally infested with $M$. javanica under a spraying irrigation system by overhead sprinklers in Mansoria Village, Giza Governorate, Egypt. The experiment consisted of 21 plots each $\left(3 \times 2 \mathrm{~m}^{2}\right)$ in area. Each plot composed of three rows with 10 holes per row. Each row was $3 \mathrm{~m}$ in length, $20 \mathrm{~cm}$ in height and $40 \mathrm{~cm}$ in width. Trichoderma spp. isolates were applied, as soil treatment before sowing, at the rate of $200 \mathrm{~g} / \mathrm{m}^{2}$. Sorghum medium only was applied for comparison control. Bio-Nematon ${ }^{\circledR}$ and chemical nematicide of Oxamyl ${ }^{\circledR}$ were applied at recommended rates as mentioned previously. After application, surface disinfected peanut seeds (cv. Giza 6) were sown at the first week of Mayof growing season in all treatments at the rate of two seeds /hole. Three plots were used as replicates for each treatment as well as the untreated controls. Irrigation, recommended fertilizer levels and agronomical practices were followed as usual in the reclaimed sandy soils without adding chemicals. The applied treatments were as follows: 1-T. harzianum, 2- T. viride, 3-T. virens, 4-Bio-Nematon ${ }^{\circledR}$, 5-Oxamyl ${ }^{\circledR}$, 6-Sorghum medium only and 7-untreated control.

\subsection{Determination of the effect of Trichoderma spp. on:}

\subsubsection{Root-knot nematode, Meloidogyne javanica}

Effects of Trichoderma spp., Bio-Nematon ${ }^{\circledR}$ and Oxamy ${ }^{\circledR}$ on population of $M$. javanica were determined at midgrowing season as well as at harvest time of peanut plants. Five sub-samples (plant rhizosphere soil and roots) were collected from each treated plot as well as the untreated controls. The soil sub-samples were thoroughly mixed and the composite sample of each plot was processed. Finally soil nematode population was extracted by method described by Barker (1985) and expressed as $\mathbf{J}_{2}$ in $250 \mathrm{~g}$ soil. The infested roots were gently taken off from soil, washed with tap water to free of debris, cut into approximately $1-2-\mathrm{cm}$ pieces and mixed with water and the numbers of the nematode stages inside $5 \mathrm{~g}$ roots $\left(\mathrm{J}_{2}\right.$, females and egg), were extracted by electric blender, galls and egg masses on plant roots $(5 \mathrm{~g})$ were also determined by using incubation method described by Young (1954). All numbers of nematode parameters were counted using a light microscope.

The reduction percentages of $\mathbf{J}_{2}$ nematode in soil were determined according to Henderson and Tilton formula (Puntener, 1981) as follows: 
Nematode reduction $\%=\{1-(\mathrm{PTA} / \mathrm{PTB} \times \mathrm{PCB} / \mathrm{PCA})\} \times 100$

where; $\mathrm{PTA}=$ population in treated plot after application; $\mathrm{BTB}=$ population in the treated plot before application; $\mathrm{PCB}=$ population in the check plot before application and $\mathrm{PCA}=$ population in the check plot after application.

The percentages of nematode reduction in total nematode stages inside the roots $\left(\mathrm{J}_{2}\right.$, females, eggs), galls and egg masses on roots per $5 \mathrm{~g}$ were calculated with respect to untreated control (nematode only) as follows.

$$
\begin{array}{|c|c|c}
\multirow{2}{*}{\text { Nematode reduction }(\%)=} & \text { Untreated control-Treated } & \multirow{2}{*}{\mathrm{X} 100} \\
\cline { 2 - 3 } & \text { Untreated control }
\end{array}
$$

\subsubsection{Root nodules numbers, plant growth and yield parameters}

Effects of Trichoderma spp., Bio-Nematon ${ }^{\circledR}$ and Oxamyl ${ }^{\circledR}$ on number of roots bacterial nodules /plant, growth parameters of peanut plants viz. Fresh \& dry weights of plant ( $\mathrm{g}$ ) as well as the peanut yield parameters viz. no. of pods / plant, weight of pods per plant $(\mathrm{g})$ and weight of 100 peanut seeds were recorded. Five peanut plants from each treated plot and untreated control, at mid grown season as well as at harvest time were obtained. The increases percentages in growth as well as yield parameters of plant in each treatment were calculated according to the following formula:

\begin{tabular}{|l|c|c|}
\hline \multirow{2}{*}{ Increase $(\%)=$} & Treated - Untreated control & \multirow{2}{*}{ X 100} \\
\cline { 2 - 3 } & Untreated control & \\
\hline
\end{tabular}

\subsubsection{Total microbial counts}

Effects of Trichoderma spp. on total count of aerobic bacteria, spore-forming bacteria and fungi in the rhizosphere of peanut plants were determined at one month after sowing as well as at mid and end of growing season by dilution method using plate count technique (Ghini et al., 2007) on suitable medium (Bridson, 1995). Fivesoil samples (200-g-soil) were taken from each plot at a depth of $15-30 \mathrm{~cm}$ and then the composite sample of each plot was processed as follows. Ten grams of each composite soil sample were separately shaken in $90 \mathrm{ml}$ of sterilized distilled water in a $250 \mathrm{ml}$ flask to give a dilution of $10^{-1}$. Then, serial dilutions of each fresh soil sample suspension were prepared up to $10^{-7}$, by transferring $1 \mathrm{ml}$ of sample suspension to $9 \mathrm{ml}$ sterilized distilled water in a test tube under sterile conditions. Four plates were prepared as replicates for each dilution of soil sample. Aliquots 1.0 $\mathrm{ml}$ of $10^{-5}-10^{-7}$ dilution were transferred separately into sterilized Petri plates filled with nutrient glucose $2 \%$ agar (NA) medium (Peptone $5 \mathrm{~g}$, Beef extract $3 \mathrm{~g}$, Glucose $20 \mathrm{~g}$, Agar $15 \mathrm{~g}$, Distilled water 1L, pH 7) for determining the aerobic bacterial count. After 2 days of incubation at $30^{\circ} \mathrm{C} \pm 2$, the resulted bacteria were recorded as a number of colony-forming units (CFU) per $10 \mathrm{~g}$ of soil. The sample dilution of $10^{-1}$ was pasteurized, at $80^{\circ} \mathrm{C}$ for $20 \mathrm{~min}$, to determine the spore-forming bacteria count. Aliquots of $1.0 \mathrm{ml}$ of $10^{-3}-10^{-5}$ dilutions was transferred separately into sterilized Petri plates filled with NA. Then, the plates were incubated for 2 days at $30{ }^{\circ} \mathrm{C} \pm 2$. The resulted spore-forming bacteria were recorded as CFU/10 g of soil. Aliquots of $1.0 \mathrm{ml}$ of each $10^{-3}$ and $10^{-4}$ dilution were transferred separately into sterilized Petri plates 
filled with Martin medium (Glucose $10 \mathrm{~g}$, Peptone $5 \mathrm{~g}, \mathrm{KH}_{2} \mathrm{PO}_{4} 1 \mathrm{~g}, \mathrm{MgSO}_{4} 0.5 \mathrm{~g}$, Rose Bengal $30 \mu \mathrm{g}$, streptomycine 0.03g, Agar 15g, Distilled water $1 \mathrm{~L}$ ) to count the total fungi. The inoculated plates were incubated at $30^{\circ} \mathrm{C} \pm 2$ for 7 days and then the count of the resulting fungi was recorded. Then, the total microbial counts, as $\log _{10}$ CFU/10g soil, were recorded as averages of microbial count atthree above sampling periods (Hammam et al., 2019).

\subsubsection{Frequency $\%$ of common fungi}

Effect of tested treatments on the frequency percentages of common fungi in the peanut rhizospheres was determined as CFU per $10 \mathrm{~g}$ of soil on Martin medium as mentioned before (Ghini et al., 2007). Five replicated plates were applied for each dilution per soil sample. Then, the plates were incubated at $30^{\circ} \mathrm{C} \pm 2$ for 7 days. The resulted fungi were identified to genera and species level according to the key of morphological and cultural characters described by Ellis (1971) and Barnett \& Hunter (1972). Each isolated fungus was counted and its frequency percentage was calculated as averages of counts of three above sampling periods, according to the following formula:

Frequency of common fungus $(\%)=($ Fungus no. / Total fungi no. $) \mathrm{X} 100$

\section{Statistical analysis}

Data of nematode reproduction and plant growth parameters were subjected to analysis of variance (ANOVA) using Computer Statistical Package (CO-STATE) User Manual Version 3.03, Barkley Co., USA. The means were compared with Duncan's multiple range tests (Snedecor and Cochran, 1999).

\section{RESULTS}

\section{1-Effect of Trichoderma spp. on root-knot nematode parameters}

Effects of the tested species of Trichoderma, in comparison with Bio-Nematon ${ }^{\circledR}$ and Oxamyl ${ }^{\circledR}$ on nematode parameters of $M$. javanica, at mid grown season and at harvest time, are summarized in Tables $(1 \& 2)$. The obtained data showed that all treatments had the potential activity to reduce the root-knot nematode reproduction, compared to untreated control. At mid-season, the nematicidal effects of applied Trichoderma spp. were more effective in reducing $\mathbf{J}_{2}$ in soil, than Bio-Nematon ${ }^{\circledR}$. The highest percentages reduction in $\mathrm{J} 2$ in soil was recorded with T.viride (being $81 \%$ ), followed by $T$. harzianum $(77 \%), T$. virens $(73 \%)$ and Bio-Nematon ${ }^{\circledR}(54 \%)$, compared to untreated control. The results showed that Bio-Nematon ${ }^{\circledR}$ gave the highest reduction in total developmental stages (63\%) and galls (70\%), followed by $T$. harzianum $(60,63 \%), T$. viride $(54,59 \%)$ and $T$. virens $(45,56 \%)$, compared to untreated control, respectively. Bio-Nematon ${ }^{\circledR}$ also highly reduced the number of egg masses (67\%), followed by T. virens (60\%), T. harzianum (53\%) and T. viride (53\%), compared to untreated control (Table 1).

At harvest time, $T$. viride (68\%), recorded the highest nematode reduction in $\mathrm{J} 2$ in soil, followed by T. harzianum (58\%), T. virens (47\%) and Bio-Nematon ${ }^{\circledR}(40 \%)$, compared to untreated control (Table 2). 
Table 1: Effect of Trichoderma spp. on Meloidogyne javanica parameters in rhizosphere and roots of peanut plants, under field conditions, at mid growing season.

\begin{tabular}{|c|c|c|c|c|c|c|c|c|c|c|c|c|}
\hline \multirow{4}{*}{ Treatments } & \multicolumn{12}{|c|}{ Nematode parameters } \\
\hline & \multirow{2}{*}{\multicolumn{3}{|c|}{$\mathbf{J}_{2}$ in soil $(250 \mathrm{~g})$}} & \multicolumn{5}{|c|}{ Developmental stages } & \multirow{2}{*}{\multicolumn{2}{|c|}{ Galls }} & \multirow{2}{*}{\multicolumn{2}{|c|}{ Egg masses }} \\
\hline & & & & \multirow{2}{*}{$\begin{array}{l}\mathrm{J}_{2} \text { in } \\
\text { roots } \\
(5 \mathrm{~g})\end{array}$} & \multirow[b]{2}{*}{ Females } & \multirow[b]{2}{*}{ Eggs } & \multicolumn{2}{|c|}{ Total } & & & & \\
\hline & Initial & $\begin{array}{c}\text { Mid - } \\
\text { season } \\
\text { no. }\end{array}$ & $\begin{array}{c}\text { Red. } \\
\%\end{array}$ & & & & No. & $\begin{array}{c}\text { Red. } \\
\%\end{array}$ & No. & Red.\% & No. & $\begin{array}{c}\text { Red. } \\
\%\end{array}$ \\
\hline T. harzianum & $111^{\mathrm{a}}$ & $201^{\mathrm{d}}$ & 77 & $120^{\mathrm{c}}$ & $120^{\mathrm{b}}$ & $240^{\mathrm{c}}$ & $480^{\mathrm{d}}$ & 60 & $10^{\mathrm{d}}$ & 63 & $7^{\mathrm{c}}$ & 53 \\
\hline T.viride & $98^{\mathrm{ab}}$ & $143^{\mathrm{c}}$ & 81 & $110^{\mathrm{c}}$ & $110^{\mathrm{b}}$ & $330^{\mathrm{b}}$ & $550^{\mathrm{c}}$ & 54 & $11^{\mathrm{cd}}$ & 59 & $7^{\mathrm{c}}$ & 53 \\
\hline T.virens & $95^{\mathrm{b}}$ & $196^{\mathrm{d}}$ & 73 & $110^{\mathrm{c}}$ & $110^{\mathrm{b}}$ & $440^{\mathrm{a}}$ & $660^{\mathrm{b}}$ & 45 & $12^{\mathrm{c}}$ & 56 & $6^{\mathrm{cd}}$ & 60 \\
\hline Bio-Nematon $^{\circledR}$ & $89^{\mathrm{b}}$ & $315^{\mathrm{c}}$ & 54 & $90^{\mathrm{d}}$ & $90^{\mathrm{c}}$ & $270^{c}$ & $450^{\mathrm{d}}$ & 63 & $8^{\mathrm{e}}$ & 70 & $5^{\mathrm{d}}$ & 67 \\
\hline Oxamyl $^{\circledR}$ & $93^{\mathrm{b}}$ & $121^{\mathrm{f}}$ & 83 & $80^{\mathrm{d}}$ & $80^{c}$ & $160^{\mathrm{d}}$ & $320^{\mathrm{e}}$ & 73 & $7^{\mathrm{e}}$ & 74 & $6^{\mathrm{cd}}$ & 60 \\
\hline Sorghum & $86^{\mathrm{b}}$ & $428^{\mathrm{b}}$ & 35 & $240^{\mathrm{b}}$ & $240^{\mathrm{a}}$ & $160^{\mathrm{d}}$ & $640^{\mathrm{b}}$ & 47 & $16^{\mathrm{b}}$ & 41 & $11^{\mathrm{b}}$ & 27 \\
\hline Untreated & $90^{\mathrm{b}}$ & $698^{\mathrm{a}}$ & - & $480^{\mathrm{a}}$ & $240^{\mathrm{a}}$ & $480^{\mathrm{a}}$ & $1200^{a}$ & - & $27^{\mathrm{a}}$ & - & $15^{\mathrm{a}}$ & - \\
\hline
\end{tabular}

* Means in each column, followed by the same small letter are not significantly different according to Duncan`multiple range test $(\mathrm{P}=0.05)$. 
Table 2: Effect of Trichoderma spp. on Meloidogyne javanica parameters in rhizosphere and roots of peanut plants, under field conditions, at harvest time.

\begin{tabular}{|c|c|c|c|c|c|c|c|c|c|c|c|c|}
\hline \multirow{4}{*}{ Treatments } & \multicolumn{12}{|c|}{ Nematode parameters } \\
\hline & \multicolumn{3}{|c|}{$\mathbf{J}_{2}$ in soil $(250 \mathrm{~g})$} & \multicolumn{5}{|c|}{ Developmental stages } & \multicolumn{2}{|c|}{ Galls } & \multicolumn{2}{|c|}{ Egg masses } \\
\hline & & & & $\mathbf{J}_{2}$ in & & & $\mathrm{Tc}$ & & & & & \\
\hline & Iinitial & No. & $\begin{array}{c}\text { Red } \\
. \%\end{array}$ & $\begin{array}{c}\text { roots } \\
(5 \mathrm{~g})\end{array}$ & Females & Eggs & No. & Red.\% & No. & Red.\% & No. & Red. $\%$ \\
\hline T. harzianum & $111^{\mathrm{a}}$ & $900^{\mathrm{e}}$ & 58 & $70^{c}$ & $140^{c}$ & $280^{\mathrm{d}}$ & $490^{g}$ & 68 & $16^{\mathrm{e}}$ & 84 & $11^{\mathrm{d}}$ & 84 \\
\hline T.viride & $98^{\mathrm{ab}}$ & $600^{f}$ & 68 & $140^{\mathrm{b}}$ & $210 b^{c}$ & $350^{\mathrm{c}}$ & $700^{\mathrm{d}}$ & 54 & $19^{\mathrm{d}}$ & 81 & $13^{\mathrm{d}}$ & 81 \\
\hline T.virens & $95^{\mathrm{b}}$ & $975^{\mathrm{d}}$ & 47 & $80^{c}$ & $240^{\mathrm{b}}$ & $240^{\mathrm{d}}$ & $560^{f}$ & 63 & $24^{\mathrm{c}}$ & 77 & $18^{\mathrm{c}}$ & 73 \\
\hline Bio-Nematon ${ }^{\circledR}$ & $89^{\mathrm{b}}$ & $1011^{\mathrm{c}}$ & 41 & $60^{c}$ & $180^{\mathrm{bc}}$ & $360^{c}$ & $600^{\mathrm{e}}$ & 60 & $20^{\mathrm{d}}$ & 80 & $12^{\mathrm{d}}$ & 83 \\
\hline Oxamyl ${ }^{\circledR}$ & $93^{\mathrm{b}}$ & $391^{\mathrm{g}}$ & 78 & $50^{c}$ & $270^{\mathrm{b}}$ & $450^{\mathrm{b}}$ & $770^{\mathrm{b}}$ & 49 & $18^{\text {de }}$ & 82 & $14^{\mathrm{cd}}$ & 80 \\
\hline Sorghum & $86^{\mathrm{b}}$ & $1244^{\mathrm{b}}$ & 25 & $\begin{array}{c}100^{b} \\
c\end{array}$ & $250^{\mathrm{b}}$ & $375^{\mathrm{c}}$ & $725^{\mathrm{c}}$ & 52 & $30^{\mathrm{b}}$ & 71 & $25^{\mathrm{b}}$ & 64 \\
\hline Untreated & $90^{\mathrm{b}}$ & $1743^{\mathrm{a}}$ & - & $300^{\mathrm{a}}$ & $550^{\mathrm{a}}$ & $660 \mathrm{a}$ & $1510^{\mathrm{a}}$ & - & $102^{\mathrm{a}}$ & - & $70^{\mathrm{a}}$ & - \\
\hline
\end{tabular}

* Means in each column, followed by the same small letter are not significantly different according to Duncan`s multiple range test $(\mathrm{P}=0.05)$. 
On the other hand, T. harzianum recorded the highest reduction in total stages of nematode (being 68\%), followed by T. virens $(63 \%)$, Bio-Nematon ${ }^{\circledR}(60 \%)$ and $T$. viride (54\%) compared to untreated control. T. harzianum (84\%) also recorded the highest reduction in number of galls, followed by T. viride $(81 \%)$ and Bio-Nematon ${ }^{\circledR}$ (80\%) and T. virens (77\%), compared to untreated control. The highest reduction in egg masses was recorded with T. harzianum (84.3\%), followed by Bio-Nematon ${ }^{\circledR}$ (83\%), T. viride (81\%) and T. virens $(73 \%)$, compared to untreated control. Results showed that Oxamyl® had the highest reduction against previous nematode criteria in some cases at mid growing season or harvest time. Sorghum medium gave the least nematode reduction, compared to untreated control (Table 2).

\section{2-Effect of Trichoderma spp. on number of root nodules}

At mid growing season, Bio-Nematon ${ }^{\circledR}$ significantly increased the number of root bacterial nodules being $100 \%$, followed by T. virens (90\%), T. harzianum (80\%) and T. viride $(40 \%)$, compared to untreated control. At harvest time, Bio-Nematon ${ }^{\circledR}$ also highly increased the number of root nodules being $40 \%$, followed by $T$. virens (33\%), T. harzianum (27\%) and T. viride (20\%), compared to untreated control. The reduction effects of Oxamyl ${ }^{\circledR}$ or Sorghum medium only are listed in Table (3).

Table 3: Effect of Trichoderma spp. on root nodules in peanut plants naturally infected with Meloidogyne javanica, under field conditions, at mid growing season and at harvest time.

\begin{tabular}{lcccc}
\hline \multirow{3}{*}{ Treatments } & \multicolumn{4}{c}{ Root nodules } \\
\cline { 2 - 5 } & \multicolumn{2}{c}{ At mid-season } & \multicolumn{2}{c}{ At harvest- season } \\
\cline { 2 - 5 } T. harzianum & No. & Increase \% & No. & Increase \% \\
\cline { 2 - 5 } T. viride & $18^{\mathrm{bc}}$ & 80 & $38^{\mathrm{bc}}$ & 34 \\
T. virens & $14^{\mathrm{d}}$ & 40 & $36^{\mathrm{cd}}$ & 20 \\
Bio-Nematon $^{\circledR}$ & $19^{\mathrm{ab}}$ & 90 & $40^{\mathrm{ab}}$ & 33 \\
Oxamyl $^{\circledR}$ & $20^{\mathrm{a}}$ & 100 & $42^{\mathrm{a}}$ & 40 \\
Sorghum & $15^{\mathrm{d}}$ & 50 & $40^{\mathrm{ab}}$ & 33 \\
Untreated & $17^{\mathrm{c}}$ & 70 & $34^{\mathrm{d}}$ & 13 \\
\hline
\end{tabular}

* Means in each column, followed by the same small letter are not significantly different according to Duncan`s multiple range test $(\mathrm{P}=0.05)$.

\section{3-Effect of Trichoderma spp. on growth and yield parameters}

At mid growing season, $T$. viride highly increased the peanut plant fresh weight being $147 \%$, followed by T. virens $(143 \%)$, T.harzianum $(113 \%)$ and Bio-Nematon ${ }^{\circledR}$ (93\%), compared to untreated control. significantly increased T.harzianum the plant dry weight being $183 \%$, followed by $T$. virens $(141 \%)$, T. viride $(86 \%)$ and BioNematon ${ }^{\circledR}(28 \%)$, compared to untreated control. Results cleared that Oxamyl® could increase the above plant growth parameters being 149 and $225 \%$, while increases were 24 and $61 \%$, with Sorghum medium only, respectively (Table, 4). Concerning to the peanut yield at harvest time, $T$. virens significantly increased the percentages of number of peanut pods/plant being $213 \%$, followed by Bio-Nematon ${ }^{\circledR}(147 \%), T$. harzianum (140\%) and T. viride (133\%), compared to untreated controls. T. viride significantly increased the percentages of weight of pod /plant being $169 \%$, followed. 
Table 4: Effect of Trichoderma spp. on growth and yield parameters of peanut plants naturally infected with Meloidogyne javanica, under field conditions, at mid of growing season and harvest time

\begin{tabular}{|c|c|c|c|c|c|c|c|c|c|c|}
\hline \multirow{4}{*}{ Treatments } & \multicolumn{10}{|c|}{ Growth and yield parameters } \\
\hline & \multicolumn{4}{|c|}{ At mid season } & \multicolumn{6}{|c|}{ At harvest time } \\
\hline & \multicolumn{2}{|c|}{$\begin{array}{l}\text { Plant Fresh weight } \\
\text { (g) }\end{array}$} & \multicolumn{2}{|c|}{$\begin{array}{l}\text { Plant Dry } \\
\text { weight }(\mathrm{g})\end{array}$} & \multicolumn{2}{|c|}{ No. of pods/ plant } & \multicolumn{2}{|c|}{ Weight of pods/plant } & \multicolumn{2}{|c|}{$\begin{array}{l}\text { Weight of } 100 \\
\text { seeds }(\mathrm{g})\end{array}$} \\
\hline & $\mathrm{G}$ & $\begin{array}{c}\text { Inc. } \\
\% \\
\end{array}$ & $\mathrm{G}$ & $\begin{array}{c}\text { Inc. } \\
\%\end{array}$ & No. & $\begin{array}{c}\text { Inc. } \\
\%\end{array}$ & G & $\begin{array}{c}\text { Inc. } \\
\%\end{array}$ & G & $\begin{array}{c}\text { Inc. } \\
\%\end{array}$ \\
\hline T. harzianum & $129.3^{b^{*}}$ & 113 & $18.1^{\mathrm{b}}$ & 183 & $36.0^{\mathrm{bc}}$ & 140 & $372.1^{\mathrm{c}}$ & 157 & $240.3^{\mathrm{d}}$ & 166 \\
\hline T. viride & $150.1^{\mathrm{a}}$ & 147 & $11.9^{c}$ & 86 & $35.0^{\mathrm{bc}}$ & 133 & $390.3^{\mathrm{b}}$ & 169 & $310.2^{\mathrm{b}}$ & 244 \\
\hline T. virens & $147.1^{\mathrm{a}}$ & 142 & $15.4^{\mathrm{ab}}$ & 141 & $47.0^{\mathrm{a}}$ & 213 & $306.4^{\mathrm{d}}$ & 111 & $240.4^{\mathrm{cd}}$ & 167 \\
\hline Bio-Nematon ${ }^{\circledR}$ & $117.5^{\mathrm{b}}$ & 93 & $8.2^{\mathrm{d}}$ & 28 & $37.0^{\mathrm{bc}}$ & 147 & $300.1^{\mathrm{d}}$ & 107 & $240.0^{c}$ & 166 \\
\hline Oxamyl $^{\circledR}$ & $151.4^{\mathrm{a}}$ & 149 & $20.8^{a}$ & 225 & $57.0^{\mathrm{a}}$ & 280 & $432.7^{\mathrm{a}}$ & 199 & $440.4^{\mathrm{a}}$ & 388 \\
\hline Sorghum & $75.2^{\mathrm{c}}$ & 24 & $10.3^{\mathrm{cd}}$ & 61 & $31.0^{c}$ & 107 & $294.2^{\mathrm{d}}$ & 103 & $230.6^{d}$ & 156 \\
\hline Untreated & $60.8^{c}$ & - & $6.4^{\mathrm{e}}$ & - & $15.0^{\mathrm{e}}$ & - & $144.9^{\mathrm{e}}$ & - & $90.2^{\mathrm{e}}$ & - \\
\hline
\end{tabular}

* Means in each column, followed by the same small letter are not significantly different according to Duncan`s multiple range test $(\mathrm{P}=0.05)$. 
by $T$. harzianum (157\%), T. virens (111\%) and Bio-Nematon ${ }^{\circledR}(107 \%)$, compared to untreated control $T$. viride significantly increased the percentages of weight of 100 peanut seeds being $244 \%$, followed by $T$. virens (167\%), T. harzianum (166\%) and Bio-Nematon ${ }^{\circledR}(166 \%)$, compared to untreated control. Oxamyl, and significantly increased percentages of above yield parameters (weight of pod /plant and the weight of 100 peanut seeds) being 280, 199 and 388\%, while Sorghum medium only improved the percentages of yields by 107, 103 and 156, respectively (Table 4),

\section{4 -Effect of Trichoderma spp. on microbial counts}

Total microbial counts of aerobic bacteria, spore-forming bacteria and fungi in peanut rhizosphere, with different treatments, as averages of microbial count at different sampling times during growing season, are listed in Table (5). The total aerobic bacterial counts were in the ranges of 6.06 to $6.24 \log 10 \mathrm{CFU} / 10 \mathrm{~g}$ soil with Trichoderma spp., higher than 5.88, 5.95, 5.91 and 5.89 $\log 10$ CFU/10g soil with BioNematon ${ }^{\circledR}$, Oxamyl®, Sorghum medium only and untreated control, respectively. The highest bacterial count was recorded with $T$. harzianum, followed by $T$. viride and $T$. virens, respectively. The spore-forming bacteria counts were in the ranges of 4.65 to $4.82 \log 10$ CFU/10g soil with Trichoderma spp., where the highest count was recorded with T. harzianum, followed by $T$. virens and $T$. viride, higher than 44.53 , 4.43 , 4.56 and $4.32 \log 10 \mathrm{CFU} / 10 \mathrm{~g}$ soil with Bio-Nematon®, Oxamyl®, Sorghum medium and untreated control, respectively. The total fungi counts were ranged from 4.91 to $4.97 \log 10$ CFU/10g soil with Trichoderma spp., higher than $4.82,4.85,4.85$ and $4.80 \log 10 \mathrm{CFU} / 10 \mathrm{~g}$ soil with treatments of Bio-Nematon ${ }^{\circledR}$, Oxamyl®, Sorghum medium and untreated control, respectively. No significant differences were recorded among treatments. The highest fungal count was recorded with $T$. viride, followed by T. virens and T. harzianum (Table 5).

Table 5: Effect of Trichoderma spp. on total microbial counts (as Log10 CFU/10g soil) in rhizosphere of peanut plants naturally infected with Meloidogyne javanica, under field conditions.

\begin{tabular}{lccc}
\hline \multirow{2}{*}{ Treatments } & \multicolumn{3}{c}{ Averages of $\log _{10}$ of total microbial counts (CFU/10g soil) } \\
\cline { 2 - 4 } & $\begin{array}{c}\text { Aerobic bacteria } \\
\left(10^{5}\right)\end{array}$ & $\begin{array}{c}\text { Spore-forming } \\
\text { bacteria }\left(10^{4}\right)\end{array}$ & $\begin{array}{c}\text { Total fungi } \\
\left(10^{4}\right)\end{array}$ \\
\hline T.harzianum & $6.24^{\mathrm{a}}$ & $4.82^{\mathrm{a}}$ & $4.91^{\mathrm{a}}$ \\
T.viride & $6.09^{\mathrm{b}}$ & $4.65^{\mathrm{b}}$ & $4.97^{\mathrm{a}}$ \\
T. virens & $6.06^{\mathrm{b}}$ & $4.69^{\mathrm{ab}}$ & $4.95^{\mathrm{a}}$ \\
Bio-Nematon $^{\circledR}$ & $5.88^{\mathrm{c}}$ & $4.53^{\mathrm{bc}}$ & $4.82^{\mathrm{a}}$ \\
Oxamyl $^{\circledR}$ & $5.95^{\mathrm{c}}$ & $4.43^{\mathrm{cd}}$ & $4.85^{\mathrm{a}}$ \\
Sorghum & $5.91^{\mathrm{c}}$ & $4.56^{\mathrm{bc}}$ & $4.85^{\mathrm{a}}$ \\
Untreated & $5.89^{\mathrm{c}}$ & $4.32^{\mathrm{d}}$ & $4.80^{\mathrm{a}}$ \\
\hline
\end{tabular}

* Means in each column, followed by the same small letter are not significantly different according to Duncan`s multiple range test $(\mathrm{P}=0.05)$.

\section{5- Effect of Trichoderma spp. on frequency \% of common fungi}

Results revealed that the fungi of Aspergillus spp., A. niger, Fusarium spp., Penicillium spp., Rhizopus nigricans, Trichoderma spp. and others (Unidentified 
Table 6: Effect of Trichoderma spp. on the frequency (\%) of common fungi in the rhizosphere of peanut plants naturally infected with Meloidogyne javanica, under field conditions.

\begin{tabular}{|c|c|c|c|c|c|c|c|}
\hline \multirow[b]{2}{*}{ Treatments } & \multicolumn{7}{|c|}{ Frequency $\%$ of common fungi } \\
\hline & $\begin{array}{l}\text { Aspergillus } \\
\text { spp. }\end{array}$ & $\begin{array}{c}\text { Aspergillus } \\
\text { niger }\end{array}$ & $\begin{array}{c}\text { Fusarium } \\
\text { spp. }\end{array}$ & $\begin{array}{c}\text { Penicillium } \\
\text { spp. }\end{array}$ & $\begin{array}{l}\text { Rhizopus } \\
\text { nigricans }\end{array}$ & $\begin{array}{c}\text { Trichoderma } \\
\text { spp. }\end{array}$ & Others \\
\hline T.harzianum & $19.3^{\mathrm{ab}}$ & $10.0^{\mathrm{bc}}$ & $10.4^{\mathrm{bc}}$ & $25.8^{\mathrm{a}}$ & $1.9^{\mathrm{c}}$ & $28.8^{\mathrm{a}}$ & $3.8^{\mathrm{c}}$ \\
\hline T.viride & $23.3^{\mathrm{a}}$ & $9.3^{\mathrm{b}}$ & $6.3^{\mathrm{b}}$ & $22.3^{\mathrm{a}}$ & $2.2^{\mathrm{b}}$ & $31.6^{\mathrm{a}}$ & $5.0^{\mathrm{b}}$ \\
\hline T. virens & $17.5^{\mathrm{b}}$ & $13.9^{\mathrm{c}}$ & $6.3^{\mathrm{d}}$ & $18.4^{\mathrm{b}}$ & $2.5^{\mathrm{e}}$ & $36.5^{\mathrm{a}}$ & $4.9^{\mathrm{d}}$ \\
\hline Bio-Nematon $^{\circledR}$ & $28.8^{\mathrm{a}}$ & $11.6^{\mathrm{b}}$ & $10.0^{\mathrm{b}}$ & $31.9^{\mathrm{a}}$ & $4.2^{\mathrm{b}}$ & $6.9^{\mathrm{b}}$ & $6.6^{\mathrm{b}}$ \\
\hline Oxamyl $^{\circledR}$ & $30.7^{\mathrm{a}}$ & $11.4^{\mathrm{b}}$ & $11.4^{\mathrm{b}}$ & $28.0^{\mathrm{a}}$ & $2.8^{\mathrm{c}}$ & $10.6^{\mathrm{b}}$ & $5.1^{\mathrm{c}}$ \\
\hline Sorghum & $23.9^{\mathrm{a}}$ & $19.4^{\mathrm{aS}}$ & $8.1^{\mathrm{b}}$ & $22.5^{\mathrm{a}}$ & $1.7^{\mathrm{b}}$ & $18.7^{\mathrm{a}}$ & $5.7^{\mathrm{b}}$ \\
\hline Untreated & $27.9^{\mathrm{a}}$ & $13.8^{\mathrm{b}}$ & $13.1^{\mathrm{bc}}$ & $29.3^{\mathrm{a}}$ & $3.6^{\mathrm{d}}$ & $7.9^{\mathrm{bc}}$ & $4.4^{\mathrm{cd}}$ \\
\hline
\end{tabular}

*Means in each column, followed by the same small letter are not significantly different according to Duncan`s multiple range test $(\mathrm{P}=0.05)$. 
fungi) were the common fungi in the rhizosphere of peanut plants under field conditions. Details of the frequencies \% of common fungi are listed in Table (6). The treatments of Trichoderma spp. increased the frequency of above fungi were in the ranges of $17.5-23.3 \%, 9.3-13.9 \%, 6.3-10.4 \%, 18.4-25.8 \%, 1.9-2.5 \%, 28.8-$ $36.5 \%$ and 3.8- 5.0\%, respectively. On the other hand, in the treatments of BioNematon ${ }^{\circledR}$, Oxamyl ${ }^{\circledR}$ and Sorghum medium the frequencies of the same fungi were in the ranges of $23.9-30.7 \%, 11.4-19.4 \%, 8.1-11.4 \%, 22.5-31.9 \%, 1.7-4.2 \%$, 6.9$18.7 \%$ and $5.1-6.6 \%$, respectively. In untreated control, the common fungi frequencies $\%$ were $27.9,13.8,13.1,29.3,3.6,7.9$ and $4.4 \%$, respectively (Table 6).

\section{DISCUSSION}

Plant-parasitic nematodes cause serious damages to many organically grown vegetables and crops, where Meloidogyne spp. (root-knot nematodes) is one of the most destructive plant-parasitic nematodes. Application of chemicals becomes widely used, but application of biological approach has a better solution, through applications of bio-agents for reducing the population of pests infecting crops. Especially, biological products were developed and with more time become marketable worldwide. Our results showed that Trichoderma spp. had suppressive effects on the parameters of $M$. javanica viz. $\mathrm{J}_{2}$ in soil and $\mathrm{J}_{2}$, females, galls and egg masses in rhizosphere or roots of peanuts under naturally infestation conditions, where the tested Trichoderma spp. subsequently increased the plant growth parameters of peanuts viz. Fresh \& dry weights of plant as well as the peanut yield parameters viz. no. of pods /plant, weight of pods per plant and weight of 100 seeds. These results are agreement with those obtained by many workers as follows; T. harzianum could suppress the soil nematode population and root galls of root-knot nematode in some soybean varieties as well as increased the plant height, the number of branches and yield of soybean (Izuogu and Abir, 2015). T. harzianum could inhibit the egg-hatching and immobilize the juveniles of $M$. incognita in vitro tests. The fungus also could manage the rootknot nematode in tomato, under greenhouse conditions, by reducing incidence, population, reproduction rate as well as number of galls and egg masses per plant (Feyisa et al., 2015). El-Nagdi and Abd-El-Khair (2017) cleared that T. harzianum highly reduced numbers of $\mathrm{J}_{2}$ in soils or roots and galls or egg masses of $M$. incognita, followed by $T$. virens and $T$. viride. The treatments could increase the growth parameters of cowpea viz., length of shoot, weight of fresh and dry shoot and number of leaves. Abd-El-Khair et al. (2018) showed that T. harzianum and T. virens combined reduced the $M$. incognita parameters in soil \& roots of eggplants in pots experiment. The treatments could increase the growth parameters of eggplants (AbdEl-Khair et al., 2018). T. harzianum either singly or combined with Saccharomyces cerevisiae showed the most nematode suppressive effect on $M$. javanica, as well as improved the peanut yield production, plant growth parameters and seed nutrient contents of peanut plants (Osman et al., 2020).

Our results revealed that Trichoderma spp. could increase the soil microbial community as total counts or frequency of fungi, comparing with other treatments as well as untreated control. Results cleared that all treatments highly reduced frequencies\% of Fusarium spp., where T.viride and T.virens resulted in the highest reduction, compared to untreated control. The frequencies of Aspergillus spp. or Penicillium spp. were highly increased in the rhizosphere treated with Bio-Nematon ${ }^{\circledR}$, Oxamyl $^{\circledR}$ and Sorghum, more than Trichodema spp. treatments. These obtained results in agreement with those recorded by Korayem et al. (2019). They documented 
that Aspergillus spp., A. niger, Fusarium spp., Penicillium spp. as well as Trichoderma spp. commonly occurred in the rhizosphere of wheat grown in different governorates of Egypt. T. hamatum and T. album could significantly reduce the occurrence of $R$. solani and $F$. solani. The treatments could increase the frequency of Aspergillus spp., then A. niger, Penicillium spp. and Trichoderma spp. comparing to the controls (Abd-El-Khair and El-Nagdi, 2014).

Trichoderma spp., as biocontrol agents against many plant pathogens, is able to infect nematode eggs and juveniles of $M$, javanica according to greenhouse and laboratory studies. T. harzianum could significantly decrease the infection of nematode and others parameters. It was able to penetrate the nematode egg mass matrix as well as could significantly decrease the nematode egg-hatching levels by activating of specific resistance-related enzymes viz. POX (peroxidase), (PPO) polyphenol oxidase and (PAL) phenylalanine ammonia lyase in inoculated plants (Sahebani and Hadavi, 2008 and Hyder et al., 2017). For example, T. harzianum reduced the incidence or pathogenicity of $M$. javanica in tomatoes (Naserinasab et al., 2011). Trichoderma spp. are widely applied in agriculture may due to their well control mechanisms. The usage of these microbial inoculants in Trichoderma-based products could attract the attention of many researchers to discover more on others benefit of Trichoderma spp. Through research works worldwide, Trichoderma spp. successes in controlling of plant diseases, improving plant growth as well as decomposition or bioremediation processes. Their secondary metabolites production play an important role in agro ecosystem and could be applied as-environmentally friendly practices (Zin and Badaluddin, 2020).

Trichoderma spp. includes a great number of strains which has potential producers of bioactive secondary metabolites against plant parasitic nematode $M$. incognita. T.harzianum and T. viride showed the highest reduction juveniles $\left(\mathrm{J}_{2} \mathrm{~s}\right)$ mortality and could inhibit egg-hatching of $M$. incognita (Khan et al., 2020). The penetration and colonization of the roots by $T$. harzianum enhanced the activity of pathogenesis related proteins up to $72 \mathrm{~h}$ post-inoculation. This effect includes the coiling of hyphal and formation of aspersoria. Application of T. harzianum (T-203) with cucumber roots highly activated chitinase, 1,3-glucanase, cellulase, and peroxidase, up to $72 \mathrm{~h}$ post-inoculation, while a chemical inducer treatment responses the plant defence through, 2,6-dichloroisonicotinic acid. The association of Trichoderma with roots reduces the root disease through activating the defense response of plants (Yedidia et al., 2000). Trichoderma, mycorrhizal or endophytic fungi are filamentous fungi successfully applied for biological controlling as agents against nematodes, as resistance inducers, for reducing the nematode damages by directly parasitism, antibiosis, paralysis or lytic enzymes production as well as minimizing the harms by spacing or resource-competition, by providing higher nutrients and water uptake to the plant, or by modifying the roots morphology. The bio-agent fungi could induce resistance on nematodes through activation of hormone-mediated viz. salicylic and jasmonic acid, strigolactones among others as plant-defense mechanisms. Altering the transport of chemical defense components through the plant or the synthesis of plant secondary metabolites and various enzymes can also contribute to enhancing plant defenses (Poveda et al., 2020).

\section{CONCLUSION}

In conclusion, the present study demonstrated that Trichoderma spp. and Purpureocilliun lilacinum can provide satisfactory control of root-knot nematode, $M$. 
javanica in peanut. Biocontrol agent did not only have suppressive effects against nematodes, but also affect the total microbial counts of aerobic bacteria, sporeforming bacteria and fungi and increased the parameters of the growth and pod of peanuts.

\section{REFERENCES}

Abd-Elgawad, M.M.M. (2014). Yield losses by phytonematodes challenges and opportunities with special reference to Egypt. Egypt. J. Agronematol. 13(1): 75-94.

Abd-El-Khair H.; El-Nagdi, Wafaa M.A.and Hammam, M. M. A. (2018). Effect of olive and castor bean oil cakes singly or combined with Trichoderma spp. on Fusarium solani and Meloidogyne incognita infecting eggplant. Middle East J. Appl. Sci. 8 (2):465-473.

Abd-El-Khair, H. and El-Nagdi, Wafaa, M.A. (2014). Field application of bio-control agents for controlling fungal root rot and root-knot nematode in potato. Arch. Phytopathol. Plant Prot. 47(10): 1218-1230.

Abd-El-Khair, H.; Haggag, Karima, H.E. and Elshahawy, I.E. (2016). Soil application of Bacillus pumilus and Bacillus subtilis for suppression of Macrophomina phaseolina and Rhizoctonia solani and yield enhancement in peanut. Intern. J. Chem.Tech. Res. 9(6): 142-152.

Al-Hazmi, A. S. and Javeed, M. T. (2016). Effects of different inoculum densities of Trichoderma harzianum and Trichoderma viride against Meloidogyne javanica on tomato. Saudi J. Biol.Sci. 23(2): 288-292.

Anonymous, (2017). Bulletin of the Agricultural statistics, Ministry of Agric. and Land Reclamation. 159 p.

Barker, K.R. (1985). Nematode extraction and bioassay In: An advanced treatise on Meloidogyne, Volume 11- Methodology (Eds K. R. Barker, C. C. Carter and J. N. Sasser). PP. 19- 35. North Carolina State University Graphics: Raleigh. North Carolina, USA.

Barnett, H.L. and Hunter, B.B. (1972). Illustrated Genera of Imperfect Fungi. Burgess Publ. Co., Minnesota, 241 p.

Bastakoti, S.; Belbase, S. ; Manandhar, S. and Arjyal, C. (2017). Trichoderma species as biocontrol agent against soil borne fungal pathogens. Nepal J. Biotechnol. $5(1): 39-45$

Bridson, E.Y. (1995). The Oxide Manual $7^{\text {th }}$ Ed., Published by Unipath Limited, Wade Koad, Basingstoke Hampshire, RG 248 PW, England.

Ellis, M.B. (1971). Dematiaceous hyphomycetes. Commw. Mycol. Inst. Kew. Surrey, England.

El-Nagdi, Wafaa, M.A. and Abd-El-Khair, H. (2017). Application of certain bacterial and fungal species for controlling Meloidogyne incognita parameters in cowpea. Intern. J. Entomol. Nematol. 3(2): 70-76.

Feyisa, B.; Lencho, A. ; Selvaraj, T. and Getaneh, G. (2015). Evaluation of some botanicals and Trichoderma harzianum for the management of tomato rootknot nematode (Meloidogyne incognita (Kofoid and White) Chitwood. Adv. Crop Sci. Technol. 4(1):1-10.

Ghini, R.F.; Patrico, R.A.; Bettiol, W.; de Almeida, M.G. and Maia, A.H.N. (2007). Effect of sewage sludge on suppressiveness to soil-borne plant pathogens. Soil Biol. Biochem. 39:2797-2805. 
Hammam, M.M.A.; El-Nagdi, Wafaa, M. A.; Abd-El-Khair, H. and Abd-Elgawad, M. M. M. (2019). Biological management of the root-knot Nematode on strawberry in Egypt.Egypt. J. Agronematol.18(1): 1-17.

Hyder, S. ;Inam-ul-Haq, M.; Bibi, S. ; Malik, A. H.; Ghuffar, S. and Iqbal, S. (2017) . Novel potential of Trichoderma spp. as biocontrol agent. J. Entomol. Zool. Studies. 5(4): 214-222.

Izuogu, N. B. and Abir, T.O. (2015). Efficacy of Trichoderma harzianumT22 as a biocontrol agent against root-knot nematode (Meloidogyne incognita) on some soybean varieties. Croat. J. Food Sci. Technol. 7 (2): 47-51.

Khan, R. A. A.; Najeeb, S.; Mao, Z.; Ling, J.; Yang, Y.; Li, Y. and Xie, B. (2020). Bioactive secondary metabolites from Trichoderma spp. against phytopathogenic bacteria and root-knot nematode. Microorganisms 8 (3): 401.

Korayem, A.M.; Mohamed, M.M.M.; Noweer, E.M.A.; Abd-El-Khair, H. and Hammam, M.M.A. (2019). Occurrence of nematode - antagonistic fungi and bacteria associated with phytonematodes in the rhizosphere of wheat grown in different governorates of Egypt. Plant Arch., 19 (Suppl. 2): 780-787.

Metwaly, Howida, A. and Zawam, Hanaa, S. (2015). Efficacy of some bioagents and nemastop compound in controlling root knot disease on peanut. J. Plant Prot. Path. Mansoura Univ. 6 (3):535 - 547.

Naserinasab, Fatemeh; Sahebani, Navazallah and Etebarian, H.R. (2011). Biological control of Meloidogyne javanica by Trichoderma harzianum BI and salicylic acid on tomato. Afri. J. Food Sci. 5(3): 276 - 280.

Osman, Hamida, A.; Ameen, Hoda, H.; Mohamed, M. and Elkelany, U. S. (2020) Efficacy of integrated microorganisms in controlling root-knot nematode Meloidogyne javanica infecting peanut plants under field conditions. Bull. Nat. Res. Centre 44:134.

Papavizas, G.C. (1985). Trichoderma and Gliocladium: biology, ecology and potential biocontrol. Ann. Rev. Phytopathol. 23: 23-54.

Poveda, J.; Abril-Urias, P. and Escobar, Carolina (2020). Biological control of plantparasitic nematodes by filamentous fungi inducers of resistance: Trichoderma, mycorrhizal and endophytic fungi. Front. Microbiol., 25. https://doi.org/ 10.3389/fmicb.2020.00992

Puntener, W. (1981). Manual for field trials in plant protection. Basle, Switzerland: Agric. Division, Ciba Geigy Limited, pp. 205.

Sahebani, N. and Hadavi, N.(2008). Biological control of the root-knot nematode Meloidogyne javanica by Trichoderma harzianum. Soil Biol .Biochem. 40 (8): 2016-2020.

Settaluri, V. S.; Kandala, C. V. K.; Puppala, N. and Sundaram, J. (2012). Peanuts and their nutritional aspects-A . Rev. Food Nutr. Sci. 3 (12): 1644-1650.

Sharon, E.; Bar-Eyal. M.; Chet. I.; Herrera-Estrella, A.; Kleifeld, O., and Spiegel, Y. (2001). Biological control of the root-knot nematode Meloidogyne javanica by Trichoderma harzianum. Phytopathology 91:687-693.

Shawky, Samaa, M.; Khalil, A.E. and Soliman, Manal, M. (2010). Non chemical control of root-knot nematode; Meloidogyne javanica on peanut in Egypt. Zagazig J. Agric. Res., 37 (1): 185 - 206.

Spiegel, Y. and Chet, I. (1998). Evaluation of Trichoderma spp. as a biocontrol agent against soilborne fungi and plant-parasitic nematodes in Israel. Integ. Pest Manag. Rev. 3:169-175.

Snedecor, G.W. and Cochran, W.G. (1999). Statistical Methods, $5^{\text {th }}$ ed. Ames (IA): Iowa State Univ. Press; p. 593. 
Yedidia, I.; Benhamou, N.; Kapulnik,Y. and Chet, I. (2000). Induction and accumulation of PR proteins activity during early stages of root colonization by the mycoparasite Trichoderma harzianum strain T-203. Plant Physiol. Biochem. 38:863-873.

Young, T. W. (1954). An incubation method for collecting migratory- endoparasitic nematodes. Plant Dis. Reptr. 38: 794-795.

Ziedan, E.H.(2000). Soil treatment with biofertilizers for controlling Peanut root and pod rot disease in Nobaria province. Egypt. J. Phytopath, 28 (2): 17-26.

Zin, N. A. and Badaluddin , N. A. (2020). Biological functions of Trichoderma spp. for agriculture applications. Ann. Agric. Sci. 65(2) : 168-178.

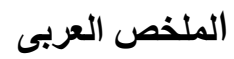

\section{التطبيق الحقلي لفظر التريكوديرما في مكافحة نيماتودا تعقد الجذور Meloidogyne javanica}

$$
\text { أسامة سامى الكيلاتى - مصطفى محمد عطيةـ وفاء محمد عبد الحميد النجدى - حسن عبد الخير أمر اض النبات. المركز القومى للبحوث. الدقى. الجيزة } 12622 \text { مصر }
$$

صمدت تجربة حقلية لدراسة تأثير ثلاثة أنو اع من الجنس Trichoderma وهم T. harzianum، Teloidogyne javanica و و T. viride السوداني ، مقارنة بالمنتج التجاري Bio-Nematon ${ }^{\circledR}$ (Purpureocillium lilacinum) و المبيد النيماتودا الكيميائي ${ }^{\circledR}$ ريزوسفير الفول السوداني بالإضافة إلى نسب تكرار الفطريات الثائعة مع المعاملات المختلفة خلال موسم النمو. أدت المعاملات المعنوية (P=0.05) إلى تقليل أعداد الطؤر اليرقى المعدى الثانى في التربة و الطؤر اليرقى المعدى الثانى والإناث وكتلة البيض في الجذور، وحسن صفات النمو الخضرى والمحصول لنبات الفول السوداني. في منتصف الموسم امتلك .Trichoderma spp. فاعلية عالية كمبيد نيماتودى أكثر من-Bio

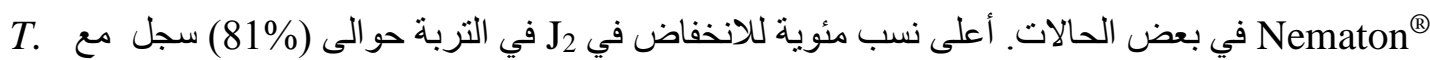

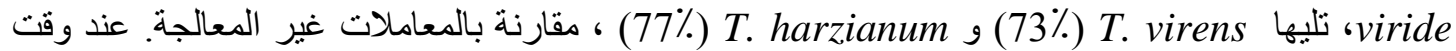

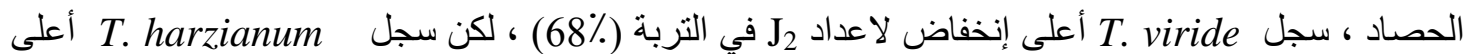
إنخفاض في إجمالي مر احل تطور النيماتودا (68\%) ، عقد الجذور النيماتودية (84\%) وكتل البيض 84\%) مقارنة بـ Bio-Nematon ${ }^{\circledR}$ T. virens و T. viride. .إختلفت الريزوسفير المعامل في إجمالي عدد الميكروبات وكذلك تكرار الفطريات الثائعة وفقًا للمعاملات المختبرة التي زادت من إجمالي عدد الميكروبات. زادت المعاملات بشكل كبير من صفات النمو الخضرى و الإنتاجية للفول السوداني كوزن طازج وجاف للنبات وكذلك

$$
\text { عدد ووزن القرون ووزن } 100 \text { بذرة من نبات الفول السودانى. }
$$

